\title{
Rectus Sheath Hematoma After Prophylactic Subcutaneous Enoxaparin Treatment in a COVID-19 Patient
}

\author{
Bir COVID-19 Hastasında Profilaktik Subkutan Enoksaparin Tedavisi Sonrası Rektus KIlıf Hematomu
}

\author{
Muharrem Bayrak', Kenan Cadirci', Mustafa Kahraman² \\ ${ }^{1}$ Department of Internal Medicine; ${ }^{2}$ Department of Radiology, Health Sciences University, Erzurum Regional Training and \\ Research Hospital, Erzurum, Turkey
}

\begin{abstract}
COVID-19 is a disease that causes microvascular thrombosis with respiratory failure. Anticoagulant treatments sometimes cause life-threatening gastrointestinal, intracranial, and abdominal bleeding. A 68-year-old male patient was admitted to the infectious diseases service because the COVID-19 PCR-RT test performed in the emergency department was positive and it was compatible with COVID-19 pneumonia on thoracic tomography. Prophylactic subcutaneous enoxaparin treatment was initiated considering that the patient would have a high risk of microvascular thrombosis due to hypertension and coronary artery disease. On the 10th day of his treatment, the patient whose general condition was deteriorated and had severe abdominal pain, hemoglobin was $6.4 \mathrm{mg} / \mathrm{dl}$ in the hemoglobin examination performed for diagnosis, and a diagnosis of hematoma spreading to the pelvis starting from the rectus sheath of $15 \times 11 \times 14 \mathrm{~cm}$ was made in abdominal tomography.
\end{abstract}

Key words: COVID-19; hematoma; enoxaparinsodium; computed tomography

\section{ÖZET}

COVID-19, solunum yetmezliği ile birlikte mikrovasküler tromboza neden olan bir hastalıktır. Antikoagülan tedaviler bazen yașamı tehdit eden gastrointestinal, intrakraniyal ve abdominal kanamaya neden olur. 68 yașındaki erkek hasta, acil serviste yapılan COVID-19 PCR-RT testinin pozitif olması ve toraks tomografisinde COVID-19 pnömonisi ile uyumlu olması nedeniyle enfeksiyon hastalıkları servisine kabul edildi. Hastanın hipertansiyon ve koroner arter hastalığına bağlı mikrovasküler tromboz riskinin yüksek olacağı düșünülerek profilaktik subkutan enoksaparin tedavisi bașlandı. Tedavisinin 10. gününde, genel durumu kötüleșen ve șiddetli karın ağrısı gelișmesi üzerine, tanı amaç/ı olarak bakılan hemoglobin incelemesinde hemoglobin 6,4 mg/dl, ve batın tomografisinde ise rektus kllfindan bașlayarak pelvise yayılan $15 \times 11 \times 14 \mathrm{~cm}$ abadlı hematom tespit edilmesi üzerine rektus kılıf hematomu tanısı konuldu.

Anahtar kelimeler: COVID-19; hematom; enoksaparinsodyum; bilgisaraylı tomografi

\section{Introduction}

COVID-19 is a highly fatal disease that causes 34 million cases and 1 million deaths in the world ${ }^{1,2}$. COVID-19 is a disease that causes microvascular thrombosis with respiratory failure ${ }^{3}$. It is thought that the formation of microvascular thrombosis in COVID-19 disease is caused by the increase in hypercoagulability caused by proinflammatory cytokines such as interleukin-6 (IL-6), tumor necrosis alpha (TNF-alpha), and other atherosclerotic changes ${ }^{4}$. Prophylactic anticoagulant treatment due to increased hypercoagulability reduces the risk of ischemia and pathologies related to microvascular thrombosis in patients with COVID-195. Rectus sheath hematoma is a rare complication and is usually seen after trauma or due to anticoagulant therapy ${ }^{6}$. Rectus sheath hematomas have a mortality rate of $4 \% \%^{7}$. Cases of rectus sheath hematoma due to low molecular weight heparin have been reported in the literature, although it is not very common $^{8}$. As far as we know in our case, we present a case of rectus sheath hematoma that developed on the 10th day of subcutaneous enoxaparin treatment, which was initiated prophylactically while receiving COVID-19 treatment. We would like to emphasize that it is very important that anticoagulant treatment and potentially fatal bleeding after treatment in COVID-19 patients require very close follow-up.

\section{Case Presentation}

The 68-year-old male patient had hypertension and coronary artery disease. The patient had been using

IIetișim/Contact: Muharrem Bayrak, Health Sciences University, Erzurum Regional Training and Research Hospital, Department of Internal Medicine, Erzurum, Turkey • Tel: 05385555933 • E-mail: muhabayrak@gmail.com • Geliș/Received:06.12.2020 • Kabul/Accepted:07.06.2021

ORCID: Muharrem Bayrak, 0000-0003-2760-4181 • Kenan Çadırcı, 0000-0002-2765-4288 • Mustafa Kahraman, 0000-0001-5573-4106 
$100 \mathrm{mg} /$ day acetylsalicylic acid and ramipril/hydrochlorothiazide $(10 / 12.5 \mathrm{mg})$ for five years. Fever of $38.6^{\circ} \mathrm{C}$ that started in the last five days, pulse $102 /$ min, respiratory rate $21 / \mathrm{min}$, blood pressure $146 / 92$ $\mathrm{mm} \mathrm{Hg}$, and oxygen saturation measurement by pulse oximetry was $79 \%$.

Bilateral breathing sounds in the lower lobes of the lungs had rales and crepitations on physical examination. In his laboratory, hemoglobin $11.8 \mathrm{~g} / \mathrm{dL}$ (14.117.8), white blood cell (WBC) $5.32 \times 10^{3}(3.91-10.9$ $\left.\mathrm{x} 10^{3}\right)$, thrombocyte $153 \times 103\left(152-383 \times 10^{3}\right)$, neutrophil $72.5 \%$ (40-74\%), lymphocyte $11.9 \%$ (\%) 17-47), absolute lymphocyte count $0.8 \times 10^{3} \mu \mathrm{L}\left(1.21-3.77 \times 10^{3}\right.$ $\mu \mathrm{L})$, serum reactive protein (crp) $48.2 \mathrm{mg} / \mathrm{L}(0-5$ $\mathrm{mg} / \mathrm{L})$, D-dimer $1590 \mathrm{mgL}(0-500 \mathrm{mgL}$, procalcitonin $0.193 \mathrm{ng} / \mathrm{ml}(0-0.05 \mathrm{ng} / \mathrm{ml})$, fibrinogen $506 \mathrm{mg} /$ dL (200-400 mg/dL), INR: 1.09 (08.1.2) (Table 1).

Table 1. Laboratory results of the COVID-19 patient on the 1st day of treatment and the 10th-day of treatment when hematoma develops

\begin{tabular}{|c|c|c|}
\hline Laboratory results & 1. Day & 10. Day \\
\hline $\begin{array}{l}\text { Hemoglobin }(\mathrm{g} / \mathrm{dL}) \\
(14.1-17.8)\end{array}$ & 11.8 & $6.4^{\star *}$ \\
\hline $\begin{array}{l}\text { White blood cell } \times 10^{3} \\
(3.91-10.9)\end{array}$ & 5.32 & 4.58 \\
\hline $\begin{array}{l}\text { Platelet } \times 10^{3} \\
(152-383)\end{array}$ & 153 & 132 \\
\hline $\begin{array}{l}\% \text { Neutrophil } \\
(\% 40-74)\end{array}$ & 72.5 & 75.6 \\
\hline $\begin{array}{l}\% \text { Lymphocyte } \\
\text { (\% 17-47) }\end{array}$ & 11.9 & 9.7 \\
\hline $\begin{array}{l}\text { Absolute lymphocyte count } \times 10^{3} \mu \mathrm{L} \\
\left(1.21-3.77 \times 10^{3} \mu \mathrm{L}\right)\end{array}$ & 0.8 & 0.6 \\
\hline $\begin{array}{l}\mathrm{CRP} \mathrm{mg} / \mathrm{L} \\
(0-5)\end{array}$ & 48.2 & 54.7 \\
\hline $\begin{array}{l}\text { D-dimer mg/L } \\
(0-500)\end{array}$ & 1590 & 1684 \\
\hline $\begin{array}{l}\text { Procalcitonin } \mathrm{ng} / \mathrm{ml} \\
(0-0.05)\end{array}$ & 0.193 & 0.254 \\
\hline $\begin{array}{l}\text { Fibrinogen } \mathrm{mg} / \mathrm{dL} \\
(200-400)\end{array}$ & 506 & 624 \\
\hline $\begin{array}{l}\text { Ferritin } \mu \mathrm{g} / \mathrm{L} \\
(30-400)\end{array}$ & 459 & 584 \\
\hline INR & 1.09 & 1.11 \\
\hline $\mathrm{S} / \mathrm{D} \mathrm{ABP} \mathrm{mmHg}$ & $146 / 92$ & $72 / 44$ \\
\hline $\mathrm{PaO}_{2} / \mathrm{FiO}_{2}$ ratio & 302 & 289 \\
\hline $\begin{array}{l}\text { GFR } \\
\left(\mathrm{ml} / \mathrm{dk} / 1.73 \mathrm{~m}^{2}\right)\end{array}$ & 79 & 62 \\
\hline
\end{tabular}

** On the 10th day, a severe decrease in hemoglobin is observed. CRP, C-reactive protein; GFR, glomerular filtration rate; INR, international normalized ratio; S/D $\mathrm{ABP}$, systolic/diastolic arterial blood pressure.
More prominent peripherally located diffuse ground glass densities were observed in all lobes, lower lobes, and subpleural areas of both lungs in the thoracic tomography of the patient, and were found to be compatible with COVID - 19 pneumonia (Figure 1). Favipiravir $2 \times 1600$ mg loading and $2 \times 600 \mathrm{mg}$ maintenance therapy, levofloxacin, $5 \mathrm{lt} / \mathrm{min}$ oxygen therapy with a nasal cannula, subcutaneous $60 \mathrm{mg} /$ day enoxaparin, acetylcysteine $900 \mathrm{mg} /$ day treatment was started for COVID-19 treatment. Acetylsalicylic acid and ramipril/hydrochlorothiazide $(10 / 12.5 \mathrm{mg})$ were continued. Daily saturation and vital signs of the patient were followed closely. Sudden onset of severe abdominal pain, nausea, vomiting, blood pressure $72 / 44 \mathrm{mmHg}$, and pulse: $118 / \mathrm{min}$. on the 10 th day of the patient's treatment. Increased sensitivity in the abdomen was observed in the physical examination of the patient. The skin and mucous membranes in the body had an anemia appearance. Hemoglobin was found to be $6.4 \mathrm{~g} / \mathrm{dL}$ in the hemogram of the patient. Unenhanced abdominal tomography was performed. A hematoma measuring $15 \times 11 \times 14 \mathrm{~cm}$ starting from the rectus sheath and continuing to the pelvic region was detected (Figure 2). The patient was transferred to the intensive care unit. Anticoagulant treatment of the patient was discontinued and intravenous fluid therapy was started at 3000 $\mathrm{ml} /$ day, 4 units of erythrocyte suspension and 2 units of fresh frozen plasma treatment were given. After the patient stayed in the intensive care unit for 7 days, a control abdominal tomography was performed because the $\mathrm{Hb}$ was $10.5 \mathrm{~g} / \mathrm{dL}$ and the condition was stable. No invasive procedure was performed on the patient as the hematoma shrank to $10 \times 11 \times 10 \mathrm{~cm}$, but a conservative treatment was applied. Our case was transferred to the normal infection service again. A written consent form was obtained from our patient to write the case.

\section{Discussion}

One of the most important causes of mortality in COVID-19 patients is venous thromboembolism and disseminated intravascular coagulopathy (DIC) 9 . COVID-19 is a disease that causes microvascular thrombosis together with respiratory failure ${ }^{3}$. It is thought that the formation of microvascular thrombosis in COVID-19 disease is caused by the increase in hypercoagulability caused by proinflammatory cytokines such as interleukin-6 (IL-6), tumor necrosis alpha (TNF-alpha), and other atherosclerotic changes $^{4}$. Proinflammatory cytokines released in COVID-19 infection are among the leading factors in 


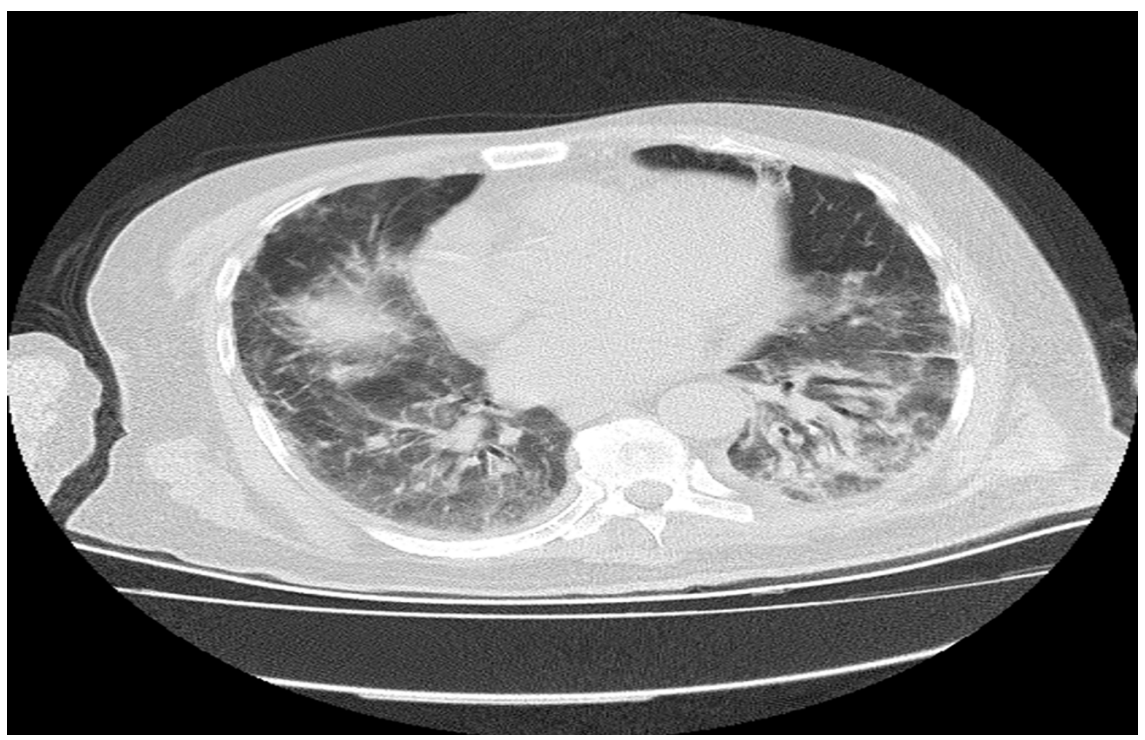

Figure 1. Thoracic tomography shows consolidated areas of peripherally located diffuse ground glass density and crazy paving findings, which are evident in the lower lobe basal segments in both lungs.

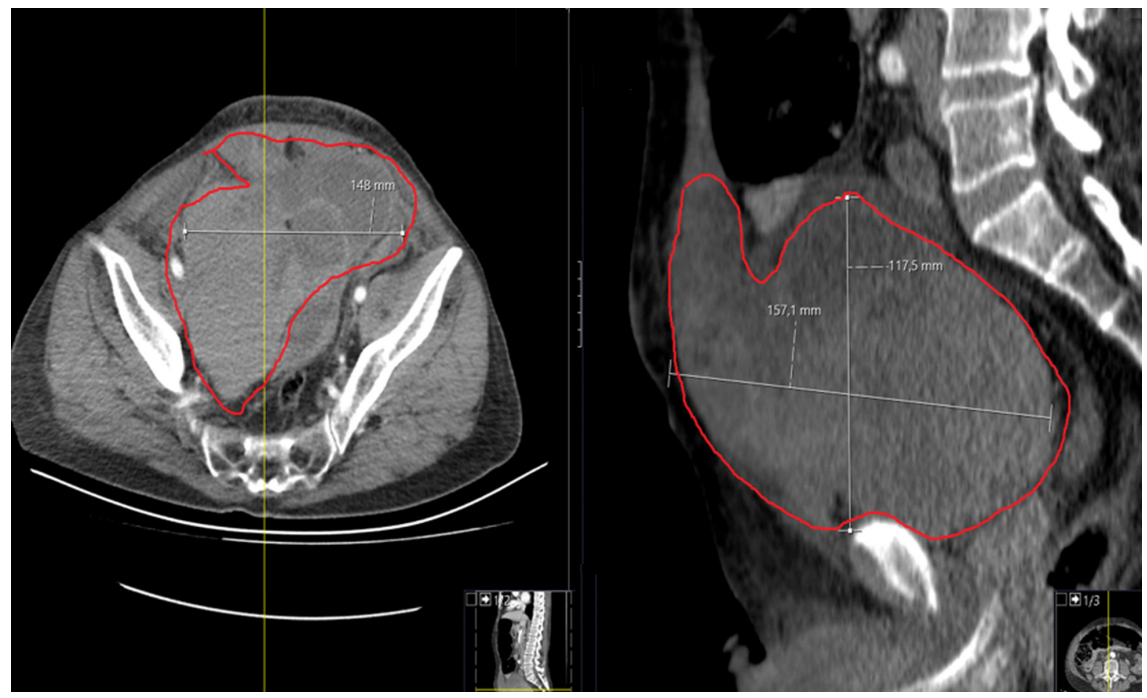

Figure 2. $15 \times 11 \times 14 \mathrm{~cm}$ hematoma image starting from the rectus sheath and extending to the pelvis and compressing the bladder on abdominal tomography.

the development of DIC ${ }^{10}$. Prophylactic anticoagulant therapy is used to prevent microvascular complications in COVID-19 infection. Our case was also using subcutaneous enoxaparin $60 \mathrm{mg}$ and $100 \mathrm{mg}$ acetylsalicylic acid. Gastrointestinal and intracranial bleeding associated with prophylactic anticoagulant treatment has been reported in patients with COVID 1911,12. To the best of our knowledge, rectus sheath hemorrhage due to subcutaneous enoxaparin has not been reported in COVID-19 infection in the literature. Patel et $\mathrm{al}^{13}$. reported a $10 \times 17 \times 24 \mathrm{~cm}$ psoas muscle hematoma in a 69-year-old male patient with COVID-19. According to the classification of rectus sheath hematoma in our case, it was classified as Type 3 because of the presence of blood in the peritoneum and prevesical space and the hematocrit being affected and in the literature ${ }^{14}$. Peripherally located ground-glass opacities, consolidated areas, reticular pattern, Crazy Paving findings are observed in thorax tomography in COVID-19 pneumonia. In our case, prevalent tomography findings consistent with the literature were observed in thorax tomography ${ }^{15}$.

Subcutaneous enoxaparin treatment was used as prophylactic and hematoma developed on the 20th day of treatment in this case. $60 \mathrm{mg}$ of enoxaparin and $100 \mathrm{mg}$ of acetylsalicylic acid were used in our case, whereas 81 $\mathrm{mg}$ of acetylsalicylic acid and $40 \mathrm{mg}$ of enoxaparin were used in the case of Patel et al. ${ }^{13}$ We think that earlier 
hematoma in our case is due to differences in drug doses, clinical and genetic differences in patients, and the fact that COVID infection causes different systemic symptoms and signs in each patient. While D-dimer was $1590 \mathrm{mg} / \mathrm{L}$ in our case, it was measured as $570 \mathrm{mg} / \mathrm{L}$ in the other case. Highness in both patients was a common feature in both patients. D-dimer height was an important factor for the initiation of prophylactic anticoagulants in our case. In the 126 case series of Cherry et al. ${ }^{6}$, which is the largest case series of rectus sheath hematoma in the literature, Median age 73 and 81 (64\%) of the patients with female rectus sheath hematoma, 87 (69\%) patients used at least one anticoagulant treatment, while $30(24 \%)$ used anticoagulant and antiplatelet therapy together. The age of the patient and the development of rectus sheath hematoma secondary to anticoagulant treatment were similar in our case, while the fact that our patient being male was different.

As a result, in COVID-19 patients, as in our case, anticoagulant therapy is used prophylactically in the existence of additional risk factors such as hypertension, coronary artery disease, as well as a serious infection (viral pneumonia, etc.), CRP, and high D-dimer and also against the risk of microvascular thrombosis due to proinflammatory cytokine release in COVID-19 infection. Anticoagulant therapy was used because of many risk factors in our case, and secondary rectus sheath hematoma developed as a complication in this treatment. We think that we contribute to the literature with the fact that our case was the first reported rectus sheath hematoma as far as we know in COVID-19 patients, and also by drawing attention to the fact that subcutaneous enoxaparin treatment, which is widely used in the treatment of COVID-19 in the world, will be a serious bleeding complication, and by reporting that patient monitoring and treatment can be performed with non-invasive conservative methods in case of a hematoma that may develop.

\section{Disclosure Statement}

No potential conflict of interest was reported by the authors.

\section{Funding}

This research did not receive any specific grant from funding agencies in the public, commercial or not-forprofit sectors.

\section{Authors' Contribution}

All authors ( $\mathrm{MB}, \mathrm{KC}$ and $\mathrm{MK}$ ) contributed equally to this manuscript and approved the final manuscript.

\section{References}

1. Johns Hopkins Coronavirus Resource Center [Internet]. JohnHopkins University \&Medicine; 2020 [cited ] 2020Available form: https://coranavirüs. jhu. edu/data/mortality.

2. Williamson EJ, Walker AJ, Bhaskaran K, Bacon S, Bates C, Morton CE, et al. Factors associated with COVID-19-related death using OpenSAFELY. Nature 2020;584(7821):430-6.

3. Connors JM, Levy JH. Thromboinflammation and the hypercoagulability of COVID-19. J Thromb Haemost 2020;18(7):1559-61.

4. Zhou F, Yu T, Du R, Fan G, Liu Y, Liu Z, et al. Clinical course and risk factors for mortality of adult inpatients with COVID-19 in Wuhan, China: a retrospective cohort study. Lancet 2020;395(10229):1054-62.

5. Connors JM, Levy JH. COVID-19 and its implications for thrombosis and anticoagulation. Blood 2020;135(23):203340.

6. Cherry WB, Mueller PS. Rectus sheath hematoma: review of 126 cases at a single institution. Medicine (Baltimore) 2006;85(2):105-10.

7. Velicki L, Cemerlić-Adić N, Bogdanović D, Mrdanin T. Rectus sheath haematoma: enoxaparin-related complication. Acta Clin Belg 2013;68(2):147-9.

8. Denard PJ, Fetter JC, Zacharski LR. Rectus sheath hematoma complicating low-molecular weight heparin therapy. Int J Lab Hematol 2007;29:190-4.

9. Dolhnikoff M, Duarte-Neto AN, de Almeida Monteiro RA, da Silva LFF, de Oliveira EP, Saldiva PHN, et al. Pathological evidence of pulmonary thrombotic phenomena in severe COVID-19. J Thromb Haemost 2020;18(6):1517-9.

10. Iba T, Levy JH, Levi M, Trachil J. Coagulopathy in COVID-19. J Thromb Haemost 2020;18(9):2103-9.

11. Gadiparthi C, Perisetti A, Sayana H, Tharian B, Inamdar S, Korman A. Gastrointestinal Bleeding in Patients with Severe SARS-CoV-2. Am J Gastroenterol 2020;115(8):1283-5.

12. Gogia B, Fang X, Rai P. Intracranial Hemorrhage in a Patient With COVID-19: Possible Explanations and Considerations. Cureus 2020;12(8): e10159.

13. Patel I, Akoluk A, Douedi S, Upadhyaya V, Mazahir U, Costanzo E, et al. Life-Threatening Psoas Hematoma due to Retroperitoneal Hemorrhage in a COVID-19 Patient on Enoxaparin Treated With Arterial Embolization: A Case Report. J Clin Med Res 2020;12(7):458-61.

14. Matalon SA, Askari R, Gates JD, Patel K, Sodickson A D, et al. Don't forget the abdominal wall: Imaging spectrum of abdominal wall injuries after nonpenetrating trauma. Radiographics 2017;37(4):1218-1235.

15. Özdemir M, Taydaş O, Öztürk M. COVID-19 Enfeksiyonunda Toraks Bilgisayarlı Tomografi Bulguları. J Biotechinol \& Strategic Health Res 2020;4:91-96. 